\title{
Construction Contractor Selection in Taiwan Using AHP
}

\author{
Fu-Yuan Chiang, Vincent F. Yu, and Pin Luarn
}

\begin{abstract}
In Taiwan, construction-project owners sometimes divide contractor selection into two phases: prequalification and final selection. The first phase entails evaluating the contractors' prequalifications and is a multi-criteria decision-making (MCDM) process, with contractors evaluated based on the weighted sum of their criteria scores. However, the criteria weights are usually determined according to the opinions of the project owners or professionals and may have some shortcomings. This study applies the analytic hierarchy process (AHP) to determine criteria weights and overcome these shortcomings. First, this study determines the appropriate evaluation criteria and constructs the hierarchical structure of the criteria. Second, experts' opinions are analyzed to calculate the following criteria weights: technical ability $(0.243)$, management capability $(0.239)$, financial soundness $(0.219)$, reputation $(0.168)$ and health and safety $(0.131)$. The model proposed in this study for evaluating contractors' prequalifications can serve as a good reference for project owners in the process of selecting contractors.
\end{abstract}

Index Terms-Contractor selection, prequalification, analytic hierarchy process.

\section{INTRODUCTION}

For construction project management, it is critical to select a qualified contractor who can meet the construction project owners' time, cost, and quality expectations. However, a construction contractor might fail to fulfill the contract requirements associated with a facility. Thus, screening qualified contractors during the selection process is very important for project owners.

In Taiwan, construction-project owners sometimes use a two-stage process to select contractors. The first stage entails evaluating contractors' prequalifications to screen for qualified contractors. The second entails comparing the bidding price of all of the qualified contractors. The contractor with the lowest total bid price will win the project. The first stage of this process-i.e., evaluating the prequalifications of the contractors - is a multicriteria decision-making (MCDM) process, with contractors evaluated based on the weighted sum of their criteria scores. The criteria weights are usually determined based on the opinions of the project owners or professionals and may have some shortcomings. Some research on prequalifications can overcome these shortcomings. More specifically, this study

Manuscript received January 5, 2016; revised March 2, 2016.

The authors are with the National Taiwan University of Science and Technology, 106 Taipei,

Taiwan (e-mail: chuckchiang.f.y@gmail.com, vincent@mail.ntust.edu.tw, luarn@ba.ntust.edu.tw). applies the Analytic Hierarchy Process (AHP) to determine the criteria weights.

\section{CONTRACTOR PREQUALIFICATION}

Contractor prequalification is a process (see Fig. 1) that uses a set of criteria either given by the project owners or based on experts' opinions to screen and determine whether a contractor can sufficiently perform a contract [1]. Contractors who wish to bid on a project need to be qualified before they can be issued bidding documents. Contractor prequalification models in the literature include the dimensional weighting aggregation model, expert systems, multiattribute analysis, fuzzy sets, logistic regression, the support vector machine (SVM), a cash-flow-based model and AHP.

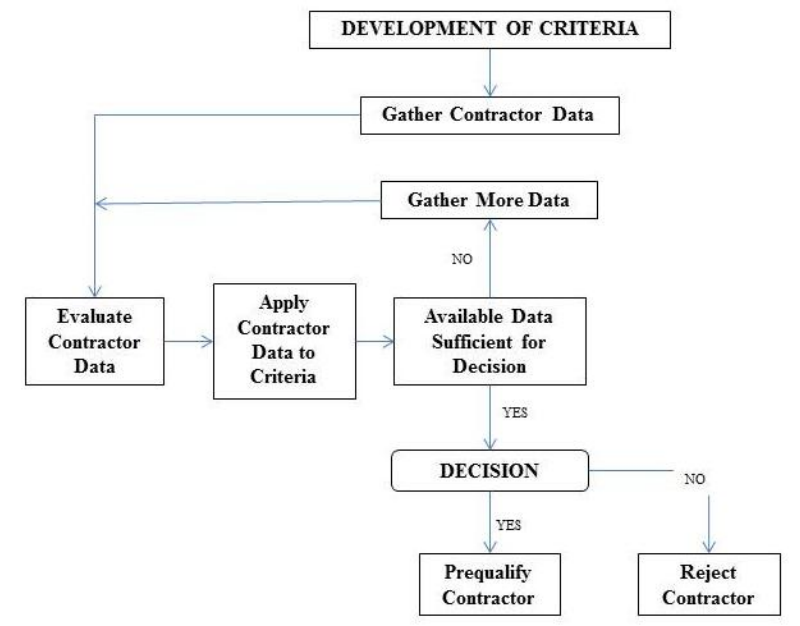

Fig. 1. Flow diagram of contractor prequalification process (Russell \& Skibniewski [1]).

Russell and Skibniewski [2] created the computer program Qualifier-1 to draw up a model with a linear combination of decision criteria. Once the rating for each decision factor is entered into the program, the aggregated weighted rating of each contractor candidate can be measured to facilitate prequalification decision making. Qualifier-2, a more advanced program than Qualifier-1 with a knowledge-based expert system, was developed by Russell et al. [3] to add decision rules into the program design and enhance the decision-making process.

Although some models strongly considered quantitative factors, they actually enhanced those factors' inherent deficiencies. This problem led to the development of a quantitative model to employ multiple variables for the analysis. The prequalification criteria entered into the model are identified and weighted to reflect the importance in the determined and selected process [4].

Contractor prequalification models bring many factors (for 
example, experience and financial standing) into the decision-making process. Although the factors provided by construction owners should be valid, some of these factors are difficult to quantify in a mathematical model. To resolve this situation, a model based on fuzzy set theory was introduced by Edyta Plebankiewicz [5].

A logistic regression (LR) model for forecasting contractor performance was developed by Wong [6] based on 31 tender-evaluation criteria. Forty-eight real projects were included in the model design. Later, this model was employed to validate 20 independent cases, proving to be $75 \%$ statistically correct in forecasting contractor performance.

Lam et al. [7] argue that contractor prequalification is nonlinear and that both quantitative and qualitative factors should be included in the model. Furthermore, they develop a new contractor prequalification model that employs a support vector machine.

Huang et al. [8] propose the adoption of a cash flow-based credit model for the prequalification of contractors' financial health because cash flows impact the ability of contractors to meet financial obligations in the construction industry.

A hybrid prequalification and selection model was developed by Abudayyeh et al. [9] to employ AHP, specifically when multiple criteria are considered. This hybrid model was leveraged by public owners to ensure that contractors can complete projects successfully.

\section{Methodology}

AHP, which was developed by Saaty [10], is a decision-aiding method that determines the relative importance weights of decision criteria. It uses a structured technique for analyzing MCDM problems based on pairwise comparisons. The strength of this approach is that AHP not only organizes quantifiable and non-quantifiable factors in a scaled systematic way but also provides a structured, relatively simple solution to decision-making problems.

The AHP process can be summarized in 4 basic steps [9]:

1) Define the problem and structure of the hierarchy using the criteria and possible solutions;

2) Construct a pairwise comparison matrix of alternatives for each criterion or subcriterion;

3) Calculate priorities;

4) Determine consistencies.

\section{A. Criteria and Hierarchic Structure}

The first contractor prequalification decision problem is to collect a set of criteria and express them as a hierarchy. The major problem solution of the decision lies at the top of the hierarchy. The criteria and sub-criteria are found on each descending level of the hierarchy. Based on the available literature review, only El-Sawalhi et al. [11] summarizes criteria from works published by several researchers (see Table I); however, an additional number of criteria for contractor prequalification have been raised (Abudayyeh et al. [9], Ng and Skitmore [12], Arslan et al. [13], Li et al. [14], Nieto-Morote and Ruz-Vila [15], Alzahrani and Emsley [16], $\mathrm{Ng}$ and Tang [17], Doloi et al. [18], Hatush and Skitmore, [19]). During the last couple of years, determining which of these criteria will become an element in the hierarchy has been a problem. Definitions for these criteria (see Table II) have been suggested by Hatch and Skitmor [19], and the hierarchic structure is shown in Fig. 2.

TABLE I: STANDING LIST OF PREQUALIFICATION CRITERIA

\begin{tabular}{|c|c|}
\hline \multicolumn{2}{|c|}{ (EL-SAWALHI ET AL. [11]) } \\
\hline Group & Attribute \\
\hline \multirow[t]{6}{*}{ Financial stability } & Credit rating \\
\hline & Turnover \\
\hline & Bank arrangement \\
\hline & Debit ratio \\
\hline & Liquidity \\
\hline & Profitability \\
\hline \multirow[t]{7}{*}{ Management and technical ability } & Experience of staff \\
\hline & Management capability \\
\hline & Qualification of staff \\
\hline & Past performance \\
\hline & Quality performance \\
\hline & Company organization \\
\hline & Innovate method \\
\hline \multirow[t]{5}{*}{ Experience } & Type of project \\
\hline & Size of project \\
\hline & Number of projects \\
\hline & Experience in the region \\
\hline & Length of time in business \\
\hline \multirow[t]{5}{*}{ Historical non-performance } & Company image \\
\hline & Skilled manpower \\
\hline & Client satisfaction \\
\hline & Record of failure \\
\hline & Claims and litigation \\
\hline \multirow[t]{2}{*}{ Resources } & Equipment \\
\hline & Number of staff \\
\hline \multirow[t]{3}{*}{ Quality } & Quality control \\
\hline & Quality policy \\
\hline & Quality assurance \\
\hline \multirow[t]{3}{*}{ Health and safety } & Safety performance \\
\hline & Accountability \\
\hline & Injury and illness \\
\hline
\end{tabular}

TABLE II: MAIN CRITERIA AND SUBCRITERIA FOR CONTRACTOR PREQUALIFICATION (HATCH \& SKITMORE [19])

\begin{tabular}{|c|c|}
\hline Main criteria & Subcriteria \\
\hline $\begin{array}{l}\text { Financial soundness } \\
\text { (FS) }\end{array}$ & $\begin{array}{l}\text { 1. Financial stability } \\
\text { 2. Credit rating } \\
\text { 3. Banking arrangements and bonding } \\
\text { 4. Financial status }\end{array}$ \\
\hline Technical ability (TA) & $\begin{array}{l}\text { 1. Experience } \\
\text { 2. Plant and equipment } \\
\text { 3. Personnel } \\
\text { 4. Ability }\end{array}$ \\
\hline $\begin{array}{l}\text { Management } \\
\text { capability (MC) }\end{array}$ & $\begin{array}{l}\text { 1. Past performance and quality } \\
\text { 2. Project management organization } \\
\text { 3. Experience of technical personnel } \\
\text { 4. Management knowledge }\end{array}$ \\
\hline Health and safety (HS) & $\begin{array}{l}\text { 1. Safety } \\
\text { 2. Experience modification rating (EMR) } \\
\text { 3. Occupational Safety and Health } \\
\text { Administration (OSHA) incidence rate } \\
\text { 4. Management safety accountability }\end{array}$ \\
\hline Reputation (R) & $\begin{array}{l}\text { 1. Past failures } \\
\text { 2. Length of time in business } \\
\text { 3. Past client/contractor relationship } \\
\text { 4. Other relationships }\end{array}$ \\
\hline
\end{tabular}

\section{B. Pairwise Comparison}

The next step is to define the relative priority of each criterion and the method Pairwise comparison is used, and only two criteria are involved in the comparison at one time. 
Subcriteria in a level of the hierarchy are pairwise and are compared to derive priorities with respect to their importance to the criteria at a higher level, starting at the top of the hierarchy and working down. The scale used for making the pairwise comparison judgments is provided in Table III [10].

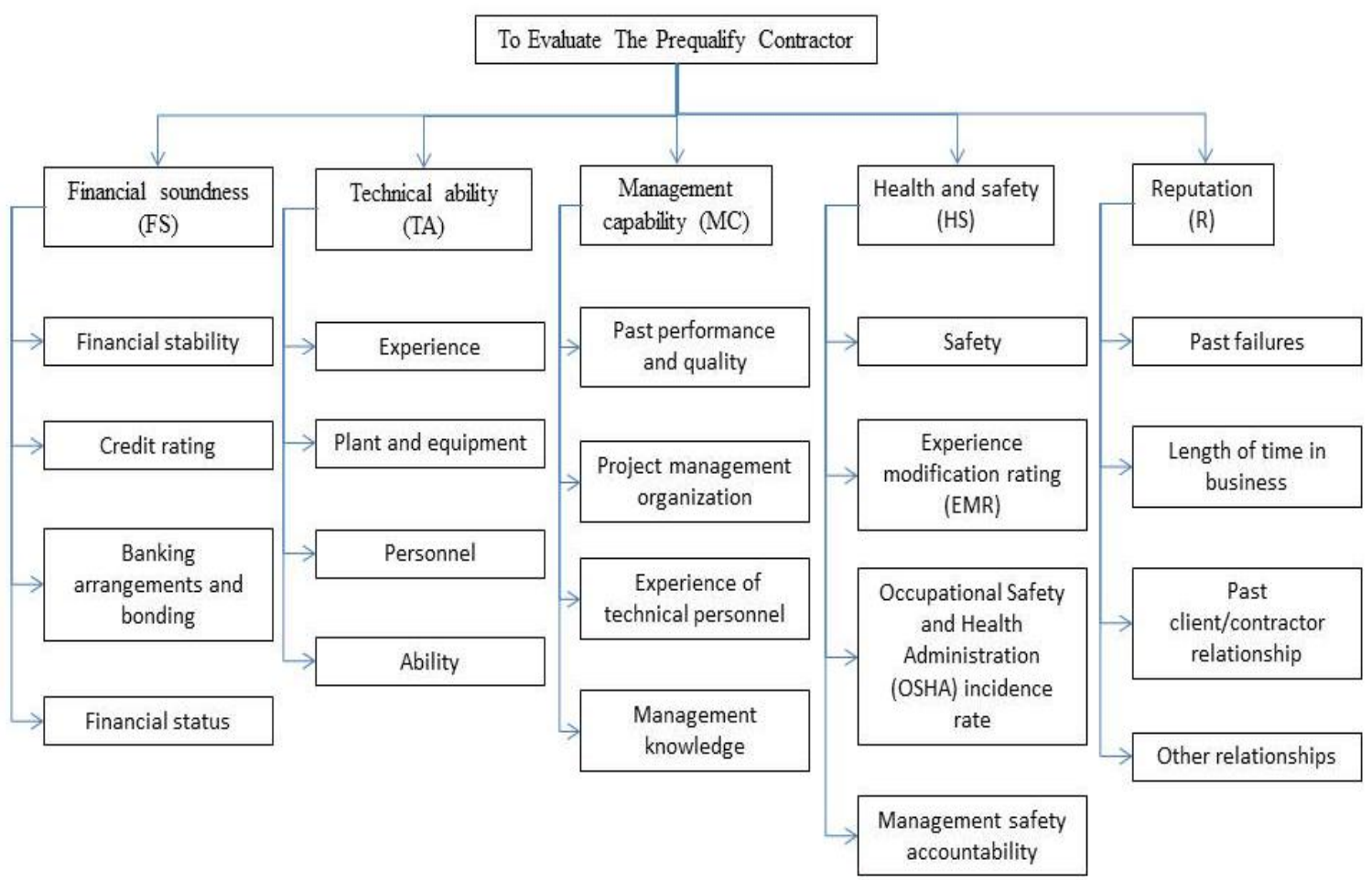

Fig. 2. Hierarchy for evaluating the prequalifications of contractors.

TABLE III: THE FUNDAMENTAL SCALE (SAATY [10])

Intensity of
importance Definition
on an
absolute

1 Equal importance equally to the objective

Moderate importance of Experience and judgment Moderate importance of strongly favor one activity one over another over another

Essential or strong Experience and judgment importance or strong strongly favor one activity over another

An activity is strongly favored and its dominance

7 Very strong importance is demonstrated in practice

The evidence favoring one activity over another is of the highest possible order of affirmation

$\begin{array}{lll}\text { Intermediate values } & \text { When compromise is } \\ \text { between the two adjacent } & \text { needed }\end{array}$ 2,4,6,8 $\quad$ between the

\section{Samples and Consistency Requirements}

During the pairwise comparison process, consider the limitation of a 9-value scale and the inconsistency in human judgment when weights are assessed. The aggregation weight vector may be invalid. The consistency index $(\mathrm{CI})$ is used to measure inconsistency. The $C I$ is defined as (1):

$$
C I=\frac{\lambda \max -n}{n-1}
$$

where $n$ is the number of criteria, and $\lambda \max$ is the maximum eigenvalue. If the consistency of the pairwise comparison results is to be accepted, the ratio (called the consistency ratio, $\mathrm{CR}$ ) of the $C I$ to that from random matrices must be significantly small (specified as approximately $10 \%$ or less). Otherwise, the pairwise comparison results must be rejected [10].

In this study, the survey targets included construction project owners and experts. Fifty questionnaires were recovered and analyzed. After eliminating inconsistent questionnaires (i.e., $C R>0.1$ ), the weight analysis included 29 valid questionnaires.

\section{RESUlts AND DisCUSSION}

The weighting results obtained using the AHP approach is shown in Table IV. Technical ability (TA) and management capability (MC) are the most important criteria for contractor prequalification. Gündüz et al. [20] analyzes the performance factors for delayed construction projects. The first three factors were lack of experience, inefficient scheduling and planning, and incompetent site management. Thus, for the owners of construction projects not only to ensure that projects are successful but also to avoid schedule delays, technical ability (TA) and management capability (MC) must be the most important criterion in evaluating the contractor-prequalification process. 
Financial soundness (FS) is the third most important criterion for contractor prequalification. Fan et al. [21] find that that among 11 industries in 39 countries, the construction industry had the second-highest mean leverage. This means that the construction industry has to rely heavily on loans and assumes higher financial risks than other industries. Li et al.
[22] find that $70 \%$ of Taiwan's construction companies default because of financial failure and bankruptcy. Therefore, project owners have an urgent need to assess contractors' financial soundness during the prequalification stage.

\begin{tabular}{|c|c|c|c|c|}
\hline Criterion & $\begin{array}{c}\text { Local } \\
\text { weight }^{\mathrm{a}}\end{array}$ & Subcriterion & $\begin{array}{l}\text { Local } \\
\text { weight }^{\mathrm{a}}\end{array}$ & $\begin{array}{l}\text { Global } \\
\text { weight }^{\mathrm{b}}\end{array}$ \\
\hline \multirow{4}{*}{ Technical ability (TA) } & \multirow{4}{*}{0.243} & Experience & 0.491 & $0.119313^{\mathrm{c}}$ \\
\hline & & Plant and equipment & 0.140 & 0.034020 \\
\hline & & Personnel & 0.148 & 0.035964 \\
\hline & & Ability & 0.221 & 0.053703 \\
\hline \multirow{4}{*}{ Management capability (MC) } & \multirow{4}{*}{0.239} & Past performance and quality & 0.293 & 0.070027 \\
\hline & & Project management organization & 0.254 & 0.060706 \\
\hline & & Experience of technical personnel & 0.257 & 0.061423 \\
\hline & & Management knowledge & 0.196 & 0.046844 \\
\hline \multirow{4}{*}{ Financial soundness (FS) } & \multirow{4}{*}{0.219} & Financial stability & 0.354 & 0.077526 \\
\hline & & Credit rating & 0.300 & 0.065700 \\
\hline & & Banking arrangements and bonding & 0.153 & 0.033507 \\
\hline & & Financial status & 0.193 & 0.042267 \\
\hline \multirow{4}{*}{ Reputation (R) } & \multirow{4}{*}{0.168} & Past failures & 0.429 & 0.072072 \\
\hline & & Length of time in business & 0.137 & 0.023016 \\
\hline & & Past client/contractor relationship & 0.255 & 0.042840 \\
\hline & & Other relationships & 0.179 & 0.030072 \\
\hline \multirow{4}{*}{ Health and safety (HS) } & \multirow{4}{*}{0.131} & Safety & 0.417 & 0.054627 \\
\hline & & Experience modification rating (EMR) & 0.146 & 0.019126 \\
\hline & & $\begin{array}{l}\text { Occupational Safety and Health Administration } \\
\text { (OSHA) incidence rate }\end{array}$ & 0.194 & 0.025414 \\
\hline & & Management safety accountability & 0.243 & 0.031833 \\
\hline
\end{tabular}

a The local weight is derived from judgment with respect to a single criterion.

b The global weight of the subcriterion is obtained by multiplying the local weight of the subcriterion by the local weight of the criterion.

c This entry is obtained as follows: $0.243 * 0.491=0.119313$.

The last two criteria weights for contractor prequalification are reputation (R) and health and safety (HS). This indicates that construction-project owners are either not very concerned about or unlikely to reference contractors' reputation and health and safety.

In this study, the following contractor prequalification model is suggested:

$$
V=\sum_{i=1}^{k} W_{i} F_{i}
$$

where $V$ is the prequalification score, $\mathrm{K}$ is the number of subcriteria, Wi is the global weight of the $\mathrm{i}$-th subcriterion, and $\mathrm{Fi}$ is the score of the $\mathrm{i}$-th subcriterion that given by the project owner or professionals. The owner can use this model to evaluate the prequalification of contractors and sort by the score $(\mathrm{V})$. The final task is to choose the higher-evaluated contractor for the second phase of bidding in the contractor-selection process.

\section{CONCLUSION}

Selecting a qualified contractor is an important task for a project owner to ensure that his project is completed within budget, on schedule and with good quality. The method of evaluating prequalifications to screen for qualified contractors and then selecting a qualified contractor with the lowest total bid price is a useful approach for project owners, giving them the opportunity to select an experienced, competitive contractor. This study proposes an approach to the multicriteria contractor selection process. Twenty quantitative and qualitative subcriteria were identified. AHP was used to rank and weight the criteria according to their importance. The contractor's technical ability and management capabilities had the highest impact when selecting contractors, with weights of $24.3 \%$ and $23.9 \%$, respectively.

\section{REFERENCES}

[1] J. S. Russell and M. J. Skibniewski, " Decision criteria in contractor prequalification," Journal of Management in Engineering, vol. 4, no. 2, pp. 148-164, Apr. 1988.

[2] J. S. Russell and M. J. Skibniewski, "Qualifier-1: Contractor prequalification model," Journal of Computing in Civil Engineering, vol. 4, no. 1, pp. 77-90, Jan. 1990.

[3] J. S. Russell, M. J. Skibniewski, and D. R. Cozier, "Qualifier-2: Knowledge-based system for contractor prequalification," Journal of Construction Engineering and Management, vol. 116, no. 1, pp. 157-171, Mar. 1990.

[4] G. D. Holt, P. O. Olomolaiye, and F. C. Harris, "Evaluating prequalification criteria in contractor selection," Building and Environment, vol. 29, no. 4, pp. 437-448, Oct. 1994.

[5] E. Plebankiewicz, "Contractor prequalification model using fuzzy sets," Journal of Civil Engineering and Managment, vol. 15, no. 4, pp. 377-385, 2009. 
[6] C. H. Wong, "Contractor performance prediction model for the United Kingdom construction contractor: study of logistic regression approach," Journal of Construction Engineering and Management, vol. 130, no. 5, pp. 691-698, Oct. 2004

[7] K. C. Lam, E. Palaneeswaran, and C. Yu, "A support vector machine model for contractor prequalification," Automation in Construction, vol. 18, nos. 3, pp. 321-329, May 2009.

[8] W. Huang, H. P. Tserng, H. Liao, S. Y. L. Yin, P. Chen, and M. C. Lei "Contractor financial prequalification using simulation method based on cash flow model," Automation in Construction, vol. 35, pp. 254-262, Nov. 2013.

[9] O. Abudayyeh, S. J. Zidan, S. Yehia, and D. Randolph, "Hybrid prequalification-based, innovative contracting model using AHP," Journal of Management in Engineering, vol. 23, no. 2, pp. 88-96, Apr. 2007.

[10] T. L. Saaty, "How to make a decision:the analytic hierarchy process," European Journal of Operational Research, vol. 48, no. 1, pp. 9-26, Sept. 1990

[11] N. El-Sawalhi, D. Eaton, and R. Rustom, "Contractor pre-qualification model: state-of-the-art," International Journal of Project Management, vol. 25 , no. 5, pp. 465-474, Jul. 2007.

[12] S. T. Ng and R. M. Skitmore, "Client and consultant perspectives of prequalification criteria," Building and Environment, vol. 34, no. 5, pp. 607-621, Sept. 1999

[13] G. Arslan, S. Kivrak, M. T. Birgonul, and I. Dikmen, "Improving sub-contractor selection process in construction projects: web-based sub-contractor evaluation system (WEBSES)," Automation in Construction, vol. 17, no. 4, pp. 480-488, May 2008.

[14] Y. Li, S. Chen, and X. Nie, "Fuzzy pattern recognition approach to construction contractor selection," Fuzzy Optimization and Decision Making, vol. 4, no. 2, pp. 103-118, Apr. 2005.

[15] A. Nieto-Morote and F. Ruz-Vila, "A fuzzy multi-criteria decision-making model for construction contractor prequalification," Automation in Construction, vol. 25, pp. 8-19, Aug. 2012.

[16] J. I. Alzahrani and M. W. Emsley, "The impact of contractors' attributes on construction project success: a post construction evaluation," International Journal of Project Management, vol. 31, no. 2, pp. 313-322, Feb. 2013.

[17] S. T. Ng and Z. Tang, "Labour-intensive construction sub-contractors: their critical success factors," International Journal of Project Management, vol. 28, no. 7, pp. 732-740, Oct. 2010.

[18] H. Doloi, K. C. Iyer, and A. Sawhney, "Structural equation model for assessing impacts of contractor's performance on project success," International Journal of Project Management, vol. 29, no. 6, pp. 687-695, Aug. 2011.

[19] Z. Hatush and M. Skitmore, "Assessment and evaluation of contractor data against client goals using PERT approach," Construction Management and Economics, vol. 15, no. 4, pp. 327-340, 1997.

[20] M. Gündüz, Y. Nielsen, and M. Özdemir, "Quantification of delay factors using the Relative importance index method for construction projects in Turkey," Journal of Management in Engineering, vol. 29 no. 2, pp. 133-139, Apr. 2013.

[21] J. P. H. Fan, S. Titman, and G. Twite, "An International comparison of Capital structure and debt maturity choices," Journal of Financial and Quantitative Analysis, vol. 47, no. 01, pp. 23-56, Feb. 2012.
[22] D. Z. Li, B. J. Wang, and K. C. Chen, The Research of Insurance and Ensure in Construction Projects, Taipei: Taiwan Construction Research Institute, 1990

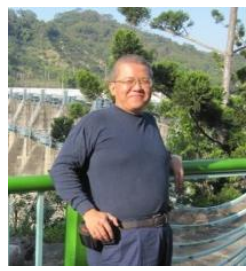

Fu-Yuan Chiang is a Ph. D. student in the Graduate Institute of Management at the National Taiwan University of Science and Technology, Taiwan. His research interests are in construction management and MCDM.

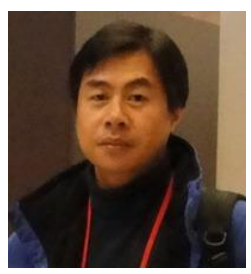

Vincent F. Yu is a professor in the Department of Industrial Management at the National Taiwan University of Science and Technology in Taiwan. He received his Ph.D. in industrial and operations engineering from the University of Michigan. His research interests are mainly in operations Research, soft computing, and logistics/supply chain management. He has published papers in Applied Mathematical Modelling, Applied Soft Computing, Computers \& Industrial Engineering, Computers \& Operations Research, European Journal of Operational Research, International Journal of Production Research, and Omega.

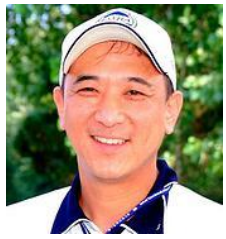

Pin Luarn is a professor in the Department of Business Administration at the National Taiwan University of Science and Technology in Taiwan. Dr Luarn received his bachelor's degree in industrial engineering from Tunghi University in Taiwan and his $\mathrm{Ph} . \mathrm{D}$. in industrial engineering from the University of Wisconsin-Madison. His academic publications have appeared in Computers in Human Behavior. Internet Research, Computers and Operations Research, Information Systems Journal, The Journal of Academic Librarianship, and other scholarly journals.

Professor Luarn was awarded the "Highly Commended Paper Award of 2014" for the article "Speech or silence: The effect of user anonymity and member familiarity on the willingness to express opinions in virtual communities" by the publisher Emerald. The article is published in the Online Information Review. 